\title{
Effects of input on L2 writing in English and Dutch
}

\section{CLIL and non-CLIL learners in French-speaking Belgium}

\author{
Luk Van Mensel, Amélie Bulon,2 Isa Hendrikx, \\ Fanny Meunier, ${ }^{2}$ \& Kristel Van Goethem ${ }^{2}$ \\ ${ }^{1}$ NaLTT, Université de Namur ${ }^{2}$ ILC, UCLouvain
}

\begin{abstract}
This study aims to explore the impact of formal and informal input on learners' variability in writing, and to compare two target-language conditions (Dutch and English) in CLIL and non-CLIL settings in Frenchspeaking Belgium. A regression model shows that CLIL is a significant predictor of $\mathrm{L}_{2}$ outcomes for both target languages, but that the relative impact of formal and informal input differs depending on the target language. In short, the amount of formal language exposure predicts the outcomes of the written productions of the learners of English, and the frequency of informal exposure those of the learners of Dutch. We argue that this observation is likely related to the difference in status that each of these languages holds among the pupils in our sample. The findings thus highlight the importance of the L2 status in research on CLIL, since different L2s can yield different results.
\end{abstract}

Keywords: L2 English, L2 Dutch, CLIL, non-CLIL, writing, Frenchspeaking Belgium

\section{Introduction}

The educational approach of Content and Language Integrated Learning (CLIL) gives equal attention to content and language by teaching a content-based subject in the target language (Dalton-Puffer, 2011). The focus is two-fold: improve pupils' L2 skills and teach them a content subject. The term CLIL is commonly used in the European context, but can also be referred to as Content-Based Instruction 
(CBI) (Cenoz, 2015). The CLIL approach may nevertheless differ from other 'immersion' programs implemented in non-European parts of the world.

A large body of recent research reports significantly higher L2 competences among pupils in CLIL than those who are learning the L2 in traditional foreign language learning settings (e.g., Admiraal, Westhoff \& de Bot, 2006; Lasagabaster, 2008; Lorenzo et al., 2005; Ruiz de Zarobe, 2008, 2010; Wesche, 2002; Zydatiß, 2007). In particular, pupils in CLIL appear to use a more diverse and more complex vocabulary, adapted to the context (Jexenflicker \& Dalton-Puffer, 2010; Lo \& Murphy, 2010; Ruiz de Zarobe, 2010; Zydatiß, 2007). Moreover, CLIL pupils are more fluent and more confident in speaking in the target language (Dalton-Puffer, 2008), and show better communication skills (e.g., Klieme, 2006; Wode, 1994) in comparison to their peers in traditional foreign language learning settings.

This said, whilst time spent on learning a second/foreign language has been recognized as one of the most important factors for successful acquisition/learning of an additional language (Kinsella, 2009; Muñoz, 2011), few studies on CLIL have explicitly controlled for the possible effect of L2 exposure (Saladrigues \& Llanes, 2014). The amount and quality of target language (TL) input has become a focus of interest for many SLA researchers (e.g., Kinsella, 2009, and Moyer, 2009, on formal and informal contact; Llanes \& Muñoz, 2009, and Pérez-Vidal \& JuanGarau, 2011, on study abroad; Long, 1983, on formal instruction). Saladrigues and Llanes (2014), for example, is one of the few CLIL studies where learners were grouped both depending on the program they belonged to (CLIL or non-CLIL) and on the amount of L2 exposure they received (high or low, according to the number of hours taking curricular and extracurricular classes). The results of this study showed no significant difference between CLIL and non-CLIL learners in terms of written fluency, accuracy, lexical complexity and syntactic complexity. However, the high versus low L2 exposure grouping revealed statistically significant higher gains for the former group.

Considering Saladrigues and Llanes' (2014) results, the present study aims to disentangle the impact of CLIL from other types of target-language input. Based on data collected in a multidisciplinary research project on CLIL in Frenchspeaking Belgium (Hiligsmann, Van Mensel, Galand, et al., 2017), we wish to examine to what extent the writing of secondary school pupils is influenced by extra TL input through CLIL and/or through informal extra-curricular contact. As our study addresses two TLs (English and Dutch), it also enables us to adopt a contrastive approach. Most research on CLIL typically considers only one TL (mainly English), and by looking at two languages we wish to investigate the impact of different TL conditions on the potential benefits of the CLIL approach. This contrastive approach is even more interesting in the context of Frenchspeaking Belgium (Communauté française), in which English and Dutch have a 
different target-language status: Dutch is one of the three official languages in Belgium (besides French and German), whereas English is a foreign language. However, students in the French community of Belgium generally encounter Dutch infrequently in day-to-day life. Dutch is spoken in the Flemish community, and the different communities have relatively much political autonomy - the education systems being organized at communal level instead of national level. Consequently, the students in the French community may be exposed as little to Dutch as to English, or may even be exposed more often to English (as a lingua franca) than to Dutch. Previous studies have also shown that Belgian pupils may have very different attitudes towards English and Dutch, with English likely to be considerably more popular than Dutch (Dewaele, 2005; Lochtman, Lutjeharms, \& Kermarrec, 2005; Mettewie, 2015). As the language of the 'other' community, the latter is often considered dull but mandatory for instrumental reasons. Since these attitudinal differences are likely to have an impact on extra-curricular exposure, it provides us with all the more reason to examine whether any differences can be found according to the target language (English vs. Dutch).

The following section provides an overview of the research on TL exposure and its impact on language learning, focusing more specifically on writing and on the learning context of CLIL. Section 3 formulates the specific research questions, and describes the participants and data set, as well as the input and outcome measures that we selected. In the fourth section, we present the results drawn from our analyses, which are further discussed in Section 5. In the final section, we wrap up with some concluding remarks.

\section{The influence of (different types of) TL input on TL proficiency}

One of the important debates in research on second and foreign language acquisition concerns the relative influence of different types of TL input on the learners' (ultimate) attainment. In the next sections, we discuss research assessing the effect of the duration of TL exposure (2.1), the role of formal vs. informal types of exposure (2.2), and the specific case of TL input in CLIL environments (2.3).

\subsection{Duration of TL learning}

Earlier research carried out in naturalistic environments (with second language learners) suggested that early starters reach higher levels of proficiency than late starters (e.g., Johnson \& Newport, 1989; Patkowski, 1980). In a similar vein, Carroll (1969) has often been quoted as a proponent of the idea that time is the most important variable in the acquisition of an L2. In this view, the amount of 
competence one achieves is largely a matter of time spent in learning. However, according to Muñoz (2011), this cannot be applied to formal language learning settings (with foreign language learners), where input never ceases to be a determinant factor. In fact, research carried out in formal environments has indicated that late starters perform at least as well as younger learners (e.g., Cenoz, 2002, 2003; García Lecumberri \& Gallardo, 2003; Miralpeix, 2006; Muñoz, 2006). In other words, starting age does not necessarily seem to be a significant factor of ultimate higher proficiency in foreign language learning contexts, as recently confirmed in two studies conducted by Muñoz (2008, 2011). What appears to be an important indicator of language proficiency outcomes in foreign language learning contexts is exposure time (Lambelet \& Berthele, 2015). In addition, studies investigating the impact of the age factor in instructional settings acknowledge the relevance of intensity of exposure in foreign language acquisition (Torras \& Celaya, 2001).

Similar observations have been made with regard to writing competence more specifically. As learners become more proficient, they write more fluently, more accurately and produce more grammatically and lexically complex texts (Wolfe-Quintero et al., 1998). Yet, growing written proficiency and duration of TL learning are not necessarily linearly correlated. Indeed, some studies looking at foreign language written production showed that an earlier start does not seem to be beneficial in written production development (Burstall, 1975; Celaya \& Navés, 2009; Celaya, Torras \& Perez-Vidal, 2001; Torras \& Celaya, 2001; Torras et al., 2006). However, in an investigation of the link between L2 competence and written production, Cumming (1994) concluded that time of exposure when learning a L2 is "a decisive factor in the level of competence attained" (as cited in Lasagabaster \& Doiz, 2003, p.141). Myles (2002) also stressed the importance of input in second language writing: "Input and interaction also play important roles in the writing process, especially in classroom settings. [...] Instruction should provide students with ample amounts of language input and instruction, as well as writing experience [...]" (pp.9-13). In sum, as argued in Munoz (2011) in instructed settings focusing on time for learning is interesting in itself.

\subsection{Formal vs informal TL exposure}

Target language exposure can be divided into two main categories. A first type of exposure refers to the amount of formal instruction the learners receive (often measured in number of years or number of curricular and possibly extracurricular hours). Johnstone (2007), for instance, in a review of findings regarding language education in Scotland, states that length of instruction appears to be positively correlated with successful learning. A second type of exposure refers to the frequency of informal contact with the TL. Informal contact with native 
speakers and/or other forms of out-of-school contact with the TL (such as gaming) clearly have a positive impact on language learning (Kinsella, 2009; Moyer, 2009; Sundqvist, 2009; Sundqvist \& Wikström, 2015). Llanes and Muñoz (2009) and Pérez-Vidal and Juan-Garau (2011), for instance, studied the linguistic gains provided by a study abroad experience and found a positive influence on different aspects of language (fluency, accuracy and listening comprehension). Research by Muñoz (2011) compared the impact of various input measures and revealed that measures of both recent and current exposure to language input (at home and abroad) as well as length of instructed exposure correlated significantly with proficiency scores. In an earlier study where she focused on learners' oral performance (Muñoz, 2008), it was found that the number of years of instruction and current informal contact significantly predicted syntactic complexity, while the number of years abroad was the best predictor of lexical diversity and accuracy. Regarding fluency, the number of years abroad and current informal contact were the best predictors. As for Mitchell et al. (2017), they explored L2 development before, during and after a temporary sojourn abroad, and its relationship with sojourners' personal development, social experience and language practices while abroad. The study focused on British undergraduates learning French or Spanish as a TL. The study offered a better understanding of informal language learning and of the complex triangular relationship between identity, personal and L2 development. All these findings suggest that different input variables affect the various components of proficiency in different ways.

\subsection{CLIL input}

If the distinction between formal and informal input has turned out to be a very fruitful one in traditional foreign language learning situations, the specific context of CLIL education entails the provision of a somewhat different type of formal input still. CLIL environments are believed to facilitate language learning since they offer more naturalistic and input-rich environments than foreign language classrooms. A substantial amount of research in CLIL has focused on learning outcomes, usually comparing the language proficiency of CLIL learners with the one of learners in traditional foreign language classes (non-CLIL learners). It is mostly hypothesized that pupils in CLIL programs will outperform their peers since they benefit from more exposure time to the L2, and this has been shown to be the case for various language aspects (notably oral production and vocabulary) (e.g., Dalton-Puffer, 2008; Jexenflicker \& Dalton-Puffer, 2010; Lo \& Murphy, 2010; Ruiz de Zarobe, 2010; Zydatiß, 2007). As far as writing skills are concerned, similar positive results have been found. Lasagabaster (2008), for instance, showed that CLIL had a positive impact on various aspects of writing 
(content, textual organization, vocabulary, grammar and spelling). Jexenflicker and Dalton-Puffer (2010) identified highly significant differences between the writing of CLIL and non-CLIL pupils for a range of measures of grammar and syntactic complexity, except for the number of subordinate clauses. Whittaker and Llinares (2011) found that CLIL pupils' writing coherence and their choice for the appropriate register improved over time. Gené-Gil, Juan-Garau and SalazarNoguera (2015) reported significant differences in the development of written complexity, accuracy and fluency of CLIL learners over a 3-year period (and only in accuracy for non-CLIL learners). Lahuerta Martínez (2015) investigated the writing of learners following bilingual and non-bilingual programs and noticed that the bilingual group surpassed the non-bilingual group in all the fluency, accuracy and lexical complexity measures. Pérez-Vidal and Roquet (2015) identified larger gains in accuracy, syntactic and lexical complexity in the writing of learners who received extra CLIL hours. Isidro and Lasagabaster (2018) found that both CLIL and non-CLIL students improved their competence in L2 English after two years of TL instruction, with significantly greater progress found in the CLIL group. In addition, the CLIL students also outperformed their non-CLIL peers in both Spanish and Galician. In contrast, Roquet and Pérez-Vidal (2017) could not confirm advantages for the CLIL students. They improved their written productive abilities, but only accuracy improved significantly. To our knowledge, and with the exception of the study by Saladrigues and Llanes (2014) mentioned in the introduction, there are no studies that investigated the impact of other exposure/ input measures on written proficiency in a CLIL context.

\section{Research questions, participants and data collection}

\subsection{Research questions}

The main purpose of this study is to assess the relative impact of different types of input variables on learners' writing performance. Given the findings in current literature on CLIL, we expect the input provided by the CLIL experience to be an important predictor of writing skills. Incidentally, previous comparative analyses on the dataset used in the present contribution (Bulon et al., 2017) yielded results that support this hypothesis. Based on a set of lexical and morpho-syntactic parameters, Bulon et al. (2017) found that the writing skills of the CLIL learners were globally more advanced than non-CLIL learners for both TLs (Dutch and English), while no significant differences were found for their first language (French) (see also Section 4.1). However, these results were not compared with the written productions of L1 control groups, and hence might need to be refined. More- 
over, besides CLIL, we wish to include formal and informal TL exposure, since both types of input appear to affect learners' (oral) proficiency in different ways (Muñoz, 2008, 2014).

Additionally, we adopt a contrastive approach (comparing Dutch and English as L2s) in order to examine whether the selected input variables influence CLIL and non-CLIL learners' writing skills in the same way depending on the TL.

More specifically, we will address the following two research questions:

i. Compared to a control group of L1 speakers, do students in CLIL display a more 'target-like' writing (in terms of text length, sentence length, word length and lexical diversity) than non-CLIL students? If so, does this more target-like writing performance manifest itself to the same extent for both TLs?

ii. To which extent does informal contact with the TL and/or the duration of TL learning have an impact on the writing performance? Are the effects of (formal and informal) input similar for both TLs (English and Dutch), or can we observe any significant differences which may be related to their different status in French-speaking Belgium?

(RQ2)

We deem it important to note that whilst it is not always necessary to compare interlanguage productions to a native reference corpus, White (2003, p.27) points the interest of a comparison of learner language to target language produced by natives; her only condition being that researchers should be careful not to judge all and any deviations from the native language as problematic. Besides, according to Ellis and Barkhuizen (2005, p.360), a learner-language/native-target-language comparison can be valuable indeed, since learners generally aim to speak their TL in a native-like manner, thus conducting a "cognitive comparison". As a result, analyzing the interlanguage according to external native norms can be psycholinguistically valid in particular cases. Granger (2015) adds that:

[f] rom a pedagogical point of view, the benefit of $\mathrm{L}_{1}-\mathrm{L}_{2}$ comparisons is even more obvious, as they provide language teaching professionals with precious information on what learners do right or wrong or partly wrong in a particular skill or task, which can be used to inform a wide range of pedagogical applications.(p.14)

\subsection{Participants}

The participants involved in this study were $412^{1}$ th year (Grade 11) Frenchspeaking secondary school learners of Dutch and English from nine secondary

1. The original sample consisted of 438 participants, but a number of texts were lost due to technical problems. 
schools in Wallonia (French-speaking Belgium). The participating schools had contrasted profiles, notably in terms of location (all provinces are covered), socioeconomic level, and education authority (official education and publicly subsidized schools) (see also Hiligsmann et al., 2017; Van Mensel et al., 2019). These schools provided CLIL programs in Dutch and/or English, along with traditional instruction (French-medium instruction with foreign language classes). The participants' ages ranged from 15 to 18 and their mean age was 16.5; 207 learners (46.7\%) were male and 231 (53.3\%) female. The CLIL learners received between 4 and 8 hours per week of content classes in the TL (depending on the school) during their fifth year. The content subjects were mostly history and geography. The distribution of the participants across the different sub-groups is described in Table 1.

Table 1. Distribution of participants across sub-groups

\begin{tabular}{lllc}
\hline$N$ & Educational setting & TL & Mean age \\
\hline 90 & CLIL & English & 16.5 \\
90 & non-CLIL & English & 16.6 \\
132 & CLIL & Dutch & 16.4 \\
100 & non-CLIL & Dutch & 16.7 \\
\hline
\end{tabular}

As regards the L1-speaker control groups, the Dutch data were collected from 59 th year Dutch-speaking secondary school students from the Netherlands and Flanders (Dutch-speaking Belgium), of whom 11 (18.64\%) were male, and 48 $(81.36 \%)$ female (average age: 16.7 years old). The data for English were collected from 65 English L1 speakers from the US (Florida), of whom 11 (16.92\%) were male, and $54(83.08 \%)$ female; their average age was slightly higher: 19.4 years old.

The slight age difference is a result of practical difficulties: collecting data from L1 English speakers under the legal age of maturity in the United Kingdom and in the United States turned out to be complex in terms of legal restrictions. Therefore, the control group of L1 English speakers consists of the youngest possible adults. While this situation may not be ideal, we believe that the data still provide a valuable benchmark.

\subsection{Data collection procedure and instruments}

The learners spent one day at the UCLouvain (in Louvain-la-Neuve, Belgium) between October and November 2015 to perform a variety of computeradministered tasks, including two writing exercises. The writing tasks consisted in writing an e-mail to a friend (min. 15 lines) on two possible topics, which were 
randomly assigned, either their last holidays or a party they attended. The task was timed (max. 25 minutes per e-mail) and we made sure the pupils had no access to online dictionaries or other reference tools. The same writing tasks were collected from the L1 reference groups in similar conditions ${ }^{2}$ between November 2015 and January 2016 for the Dutch-speaking group, and one year later for the English-speaking group. A few texts were lost due to technical problems, but as Table 2 shows, we were able to collect a total of 412 learner and 130 L1 productions. $^{3}$

Table 2. Number of texts and number of words collected

\begin{tabular}{lllllll}
\hline & $\begin{array}{l}\text { Dutch } \\
\text { L1 }\end{array}$ & $\begin{array}{l}\text { Dutch } \\
\text { CLIL }\end{array}$ & $\begin{array}{l}\text { Dutch non- } \\
\text { CLIL }\end{array}$ & $\begin{array}{l}\text { English } \\
\text { L1 }\end{array}$ & $\begin{array}{l}\text { English } \\
\text { CLIL }\end{array}$ & $\begin{array}{l}\text { English non- } \\
\text { CLIL }\end{array}$ \\
\hline Texts & 61 & 132 & 100 & 69 & 90 & 90 \\
Words & 16262 & 37209 & 19399 & 23016 & 29394 & 23747 \\
\hline
\end{tabular}

Since we collected written productions in two different languages, we had to select different appropriate tools to analyze the texts. For the English texts, we used Coh-Metrix (Graesser, McNamara, Louwerse \& Cai, 2004, p.93), for the Dutch texts T-Scan (Pander Maat et al., 2014). As both computational tools offer a large number of measures, some being similar for the two languages and others specific to one language only, a selection of shared indices had to be performed (see also Bulon et al., 2017). In order to get an overall evaluation of the pupils' writing, we selected the following four measures:

- text length, measured through the number of words per text, as a proxy of fluency;

- sentence length, measured through the number of words per sentence, as a proxy of syntactic complexity; ${ }^{4}$

- word length, measured through the number of syllables per word, as a proxy of morpho-syntactic complexity; and

2. The test was also computer-administered, under the supervision of a researcher or teacher.

3. The texts were semi-automatically corrected for punctuation mistakes (missing spaces after commas and full stops were added) to increase the accuracy of the measures. As correcting the spelling and grammatical errors of a selection of texts did not significantly improve the accuracy of the measures, this suggests that these types of errors were not frequently found (Bulon et al., 2017), and therefore these were not corrected in the remainder of the corpus.

4. We are aware of the fact that the T-unit has frequently been proposed as a more effective unit to assess complexity at the sentence level. However, neither Coh-Metrix nor T-scan provided that measure. 
- MTLD (Measure of Textual Linguistic Diversity), ${ }^{5}$ indicating lexical diversity.

While we are well aware that such measures offer only a partial view on writing skills (and that other aspects should be taken into account to obtain a refined view of the learners' proficiency), these measures have been widely used in assessing complexity and fluency in learners' productions (see Mitchell et al., 2017, for more examples and comments). They allowed us to get proxies of proficiency for all our learners and for the two TLs.

The input measures (besides CLIL) used to investigate the potential impact of L2 input on the learners' written proficiency are based on Muñoz's work (2011, 2014) and are derived from student questionnaires (see Appendix 1):

- length of TL instruction in years, a measure of cumulative exposure to formal input, and

- current informal contact with the TL, a composite measure consisting of frequency of internet use in the TL, frequency of TL (productive and receptive) use outside school and frequency of contact with native speakers outside school.

We also included the pupils' nonverbal intelligence (Raven test-score, see Raven, Court \& Raven, 1998) as a control variable in our analysis. As discussed in Bulon et al. (2017) and Simonis et al. (2019), among the pupils learning Dutch as a second language, the CLIL and the non-CLIL pupils differed significantly in their Raven scores, whilst this was not the case for the English learners. These differences may be due to an (auto-)selection effect for Dutch CLIL (see Van Mensel et al., 2019, for details). In order to preclude any effects related to a bias in the sample, we thus deemed it wise to add Raven scores as a control variable.

\section{Results}

\subsection{Descriptive statistics}

In Tables $3 a$ and $3 b$, we provide an overview of the descriptive statistics for the two target languages and for all selected variables, broken down according to the two TL conditions.

5. MTLD is calculated as the "mean length of sequential word strings in a text that maintain a given TTR value" (McCarthy \& Jarvis, 2010, p.385). Koizumi (2012) found that MTLD was least affected by text length compared to TTR and other recent indices (e.g., Guiraud index and D), when used with texts of at least 100 tokens. Furthermore, the measure appears to be a good predictor of overall L2 proficiency (Crossley, Salsbury \& McNamara, 2014; Treffers-Daller, 2013). 
Table 3a. Descriptive statistics English

\begin{tabular}{|c|c|c|c|c|c|c|}
\hline & \multicolumn{6}{|c|}{ English } \\
\hline & \multicolumn{2}{|c|}{ L1-speakers } & \multicolumn{2}{|c|}{ CLIL } & \multicolumn{2}{|c|}{ Non-CLIL } \\
\hline & Mean & $S D$ & Mean & $S D$ & Mean & $S D$ \\
\hline \multicolumn{7}{|l|}{ Outcome variables $T L$} \\
\hline Text length (words/text) & 333.57 & 87.99 & 326.52 & 63.81 & 263.86 & 83.35 \\
\hline Sentence length (words/sentence) & 23.39 & 6.51 & 15.48 & 5.93 & 12.81 & 5.39 \\
\hline Word length (syllables/word) & 1.33 & 0.06 & 1.29 & 0.05 & 1.31 & 0.05 \\
\hline Lexical diversity (MTLD) & 95.53 & 22.07 & 72.99 & 16.41 & 62.07 & 14.27 \\
\hline \multicolumn{7}{|l|}{ Input variables } \\
\hline Length of TL instruction (in years) & - & - & 6.23 & 3.00 & 5.05 & 2.24 \\
\hline Current informal contact with $\mathrm{TL}^{\mathrm{a}}$ & - & - & 3.42 & 0.81 & 3.02 & 0.87 \\
\hline \multicolumn{7}{|l|}{ Control variable } \\
\hline Raven score & - & - & 43.67 & 6.21 & 41.82 & 7.78 \\
\hline
\end{tabular}

a. Frequency of informal contact with the TL outside school (composite measure, Cronbach's alpha .78, see Appendix 1), on a scale from 1 to 5 (never - rarely - sometimes - often - very often)

Table 3 b. Descriptive statistics Dutch

\begin{tabular}{|c|c|c|c|c|c|c|}
\hline & \multicolumn{6}{|c|}{ Dutch } \\
\hline & \multicolumn{2}{|c|}{ L1 speakers } & \multicolumn{2}{|c|}{ CLIL } & \multicolumn{2}{|c|}{ Non-CLIL } \\
\hline & Mean & $S D$ & Mean & $S D$ & Mean & $S D$ \\
\hline \multicolumn{7}{|l|}{ Outcome variables $T L$} \\
\hline Text length (words/text) & 222.18 & 67.298 & 280.95 & 57.79 & 193.99 & 59.76 \\
\hline Sentence length (words/sentence) & 12.49 & 4.09 & 11.27 & 3.13 & 9.40 & 2.48 \\
\hline Word length (syllables/word) & 1.27 & 0.24 & 1.28 & 0.05 & 1.23 & 0.06 \\
\hline Lexical diversity (MTLD) & 94.41 & 26.22 & 74.05 & 16.09 & 61.04 & 17.99 \\
\hline \multicolumn{7}{|l|}{ Input variables } \\
\hline Length of TL instruction (in years) & - & - & 9.20 & 2.67 & 7.73 & 2.48 \\
\hline Current informal contact with $\mathrm{TL}^{\mathrm{a}}$ & - & - & 2.54 & 0.78 & 2.05 & 0.73 \\
\hline \multicolumn{7}{|l|}{ Control variable } \\
\hline Raven score & - & - & 46.04 & 6.90 & 42.41 & 7.97 \\
\hline
\end{tabular}

a. Frequency of informal contact with the TL outside school (composite measure, Cronbach's alpha .78, see Appendix 1), on a scale from 1 to 5 (never - rarely - sometimes - often - very often) 
With respect to our first research question (cf. 3.1), Tables $3 \mathrm{a}$ and $3 \mathrm{~b}$ show that, overall, the CLIL learners of both English and Dutch display more target-like scores than the non-CLIL learners for the examined parameters. Both CLIL groups wrote substantially longer texts than the non-CLIL pupils. In the case of English, the CLIL texts were in this sense very similar to those produced by the control group, whereas for Dutch the CLIL pupils produced even longer texts than the L1 speakers. Next, both the scores for sentence length (number of words per sentence) and lexical diversity (MTLD) are higher and more target-like in the English and the Dutch texts written by CLIL pupils than in the texts written by non-CLIL pupils, suggesting a more advanced syntactic competence and a richer vocabulary. Word length (syllables per word) is more target-like in the Dutch texts written by CLIL pupils than in the texts written by non-CLIL pupils (on average the CLIL pupils produce even slightly longer Dutch words than the natives), but this tendency is not present in the English texts. Previous comparative analyses on these outcomes only (Bulon et al., 2017) indicated that the differences between the CLIL and non-CLIL learner groups are statistically significant, but the effect sizes appeared to be larger for Dutch than for English (see Appendix 2). Hence, while there is a more clear-cut difference in terms of writing skills between CLIL and non-CLIL learners of Dutch, this seems to be less the case for learners of English.

We can equally observe in Table $3 \mathrm{~b}$ that the length of TL instruction in years is higher among the pupils learning Dutch than among those learning English in our sample (Table 3a). Among the learners of both languages, the CLIL pupils received more years of formal TL exposure. By contrast, the current informal contact with the TL is higher among the pupils learning English than among those learning Dutch. In addition, the CLIL pupils of both languages had more current informal contact with the TL than the pupils who are not in CLIL. In the following section, we analyze if and how the differences observed in the written production measures, duration of TL teaching, informal TL contact and Raven scores correlate. To do so, we first calculate correlation scores; in a second step, we fit the measures in a regression model.

\subsection{Correlations}

In order to compare the strength of association between the selected measures for written production on the one hand and the independent and control variables on the other hand, we ran Pearson correlations for each of the TLs separately. Table 4 shows the correlations between the outcome measures and the independent variables - CLIL, Raven score (nonverbal intelligence), length of TL exposure, and current informal contact with the TL - for the English texts. 
Table 4. Correlations for English

\begin{tabular}{|c|c|c|c|c|}
\hline & $\begin{array}{l}\text { Text length } \\
\text { (words/text) }\end{array}$ & $\begin{array}{l}\text { Sentence length } \\
\text { (words/sentence) }\end{array}$ & $\begin{array}{l}\text { Word length } \\
\text { (syllables/ } \\
\text { word) }\end{array}$ & $\begin{array}{l}\text { Lexical } \\
\text { diversity } \\
\text { (MTLD) }\end{array}$ \\
\hline $\operatorname{CLIL}(n=180)$ & $.391^{\star \star}$ & $.231^{\star \star}$ & $-.149^{*}$ & $.336^{\star *}$ \\
\hline Raven Score $(n=178)$ & .106 & -.080 & -.128 & .067 \\
\hline $\begin{array}{l}\text { Length of TL } \\
\text { instruction in years } \\
(n=170)\end{array}$ & $.296^{\star *}$ & .144 & $.152^{*}$ & $.360^{* *}$ \\
\hline $\begin{array}{l}\text { Current informal } \\
\text { contact with TL } \\
(n=176)\end{array}$ & $.236^{\star *}$ & .128 & -.036 & $.161^{\star}$ \\
\hline
\end{tabular}

CLIL significantly correlates with all the written production measures, something we had hypothesized given the results of our previous analyses discussed above. In contrast, the Raven score does not correlate with any of the outcome variables, suggesting a limited impact - if any - of the pupils' non-verbal intelligence on their written production. Length of TL instruction correlates with text length, word length ${ }^{6}$ and lexical diversity, while sentence length (number of words per sentence) does not expand with number of years of exposure to the TL. Finally, current informal contact correlates significantly with two out of four measures, namely words per text and lexical diversity (MTLD). Taken together, the correlations presented here lead us to suspect that for written English production, besides the (expected) impact of CLIL, the two proposed input measures impact text length (fluency) and lexical diversity, while differences at a more granular level of writing (word and sentence length) seem less affected.

Table 5 shows the correlations between the outcome measures and the independent variables - CLIL, Raven score, length of TL exposure, and current informal contact with the TL - for the Dutch texts.

Here again, the CLIL variable significantly correlates with all four measures of written production. In contrast to the English texts, the pupils' non-verbal intelligence also correlates with two of the outcome measures, namely word length and lexical diversity. This observation can be explained by the reported significant differences in Raven scores between the pupils in CLIL and non-CLIL contexts learning Dutch (Simonis et al., 2019; Van Mensel et al., 2019), differences that

6. We should, however, note that the $\mathrm{p}$ value of the correlation between word length and length of TL exposure is only just below the cut-off point of .05 (.048). 
Table 5. Correlations for Dutch

\begin{tabular}{lcccc}
\hline & $\begin{array}{c}\text { Text length } \\
\text { (words/text) }\end{array}$ & $\begin{array}{c}\text { Sentence length } \\
\text { (words/sentence) }\end{array}$ & $\begin{array}{c}\text { Word length } \\
\text { (syllables/ } \\
\text { word) }\end{array}$ & $\begin{array}{c}\text { Lexical } \\
\text { diversity } \\
\text { (MTLD) }\end{array}$ \\
\hline CLIL $(n=232)$ & $.594^{* *}$ & $.309^{* *}$ & $.367^{* *}$ & $.357^{* *}$ \\
Raven Score $(n=227)$ & $.159^{*}$ & -.050 & $.293^{* *}$ & $.268^{* *}$ \\
$\begin{array}{l}\text { Length of TL } \\
\text { instruction in years }\end{array}$ & $.264^{* *}$ & $.150^{*}$ & .088 & $.232^{* *}$ \\
$(n=219)$ & & & $.228^{* *}$ \\
$\begin{array}{l}\text { Current informal } \\
\text { contact with TL }\end{array}$ & $.333^{* *}$ & $.136^{*}$ & .127 & \\
$(n=222)$ & & & \\
\hline${ }^{*} p<.05$ (two-tailed) & $* * p<.01$ (two-tailed) & &
\end{tabular}

were not found for the English TL learners. Length of TL exposure correlates with text length, sentence length and lexical diversity. Word length (number of syllables per words) does not increase with the number of years of exposure to the TL. Finally, current informal contact with the TL (Dutch) correlates with three out of four of the measures, namely text length, sentence length and lexical diversity (MTLD). Although the correlation coefficients and the strength of the correlations for these Dutch productions differ somewhat from those presented above for English, the overall picture provided shows some similarities. Putting aside the differences with respect to the pupils' non-verbal intelligence scores, the input measures consistently correlate with text length and lexical diversity for both TLs, whereas sentence length and word length are less affected.

In order to answer our second research question (cf. 3.1), i.e., to gauge the relative effects of the different input measures on the pupils' written production, we conducted a set of multiple regression analyses. All assumptions required for this analysis were met and there was no collinearity between the independent variables.

\subsection{Regressions}

Table 6 shows the outcomes of the regression model for the English texts. The CLIL variable appears consistently as a significant predictor for all four measured dependent variables, albeit negatively for the number of syllables per word (cf. also the negative correlation in Table 4 above). The pupils' non-verbal intelligence as measured by the Raven test, on the contrary, does not appear to have any impact on any of the production measures for the English texts. Regarding the 
two input variables, we can observe how the length of TL instruction significantly predicts text length, word length and lexical diversity, whereas current informal contact with English outside school does not predict the pupils' writing skills in a significant way. Interestingly, the model is substantially better at explaining the variance in the pupils' scores for text length and lexical diversity (around 20\%) than for the other two measures (slightly more than 7\%), which echoes the correlational tendencies presented above.

Table 6. Regression models for the English written productions. (ns=not significant)

\begin{tabular}{|c|c|c|}
\hline Measures & Regression coefficient and t-test statistic & $\begin{array}{l}\text { Coefficient of determination }{ }^{7} \text { and } \\
\text { F-ratio }\end{array}$ \\
\hline Text length & $\begin{array}{l}\text { CLIL }(\beta=.320, t=4.39, p<.001) \\
\text { Raven }-n s \\
\text { Length of TL instruction }(\beta=.206, t=2.91, \\
p<.01) \\
\text { Current informal contact with TL }-n s\end{array}$ & $\begin{array}{l}\left(R^{2}=.219, F(4,164)=11.475,\right. \\
p<.001)\end{array}$ \\
\hline $\begin{array}{l}\text { Sentence } \\
\text { length }\end{array}$ & $\begin{array}{l}\text { CLIL }(\beta=.210, t=2.64, p<.01) \\
\text { Raven }-n s \\
\text { Length of TL instruction }-n s \\
\text { Current informal contact with TL }-n s\end{array}$ & $\left(R^{2}=.073, F(4,164)=3.223, p<.05\right)$ \\
\hline Word length & $\begin{array}{l}\text { CLIL }(\beta=-.167, t=-2.11, p<.05) \\
\text { Raven }-n s \\
\text { Length of TL instruction }(\beta=.202, t=2.62, \\
p<.05) \\
\text { Current informal contact with TL }-n s\end{array}$ & $\left(R^{2}=.075, F(4,164)=3.311, p<.05\right)$ \\
\hline $\begin{array}{l}\text { Lexical } \\
\text { diversity }\end{array}$ & $\begin{array}{l}\operatorname{CLIL}(\beta=.246, t=3.341, p<.01) \\
\text { Raven }-n s \\
\text { Length of TL instruction }(\beta=.301, t=4.192 \text {, } \\
p<.001) \\
\text { Current informal contact with TL }-n s\end{array}$ & $\begin{array}{l}\left(R^{2}=.202, F(4,164)=10.352,\right. \\
p<.001)\end{array}$ \\
\hline
\end{tabular}

The results of the same regression analyses for the Dutch texts provide a somewhat different picture, as can be seen in Table 7. Again, CLIL remains a significant predictor for all selected measures, but also the pupils' nonverbal intelligence shows a significant relationship with three out of four measures: word length, sentence length, and lexical diversity. Furthermore, current informal contact with the TL (Dutch) is significantly related to text length and lexical diversity, whereas length of TL instruction does not predict any of the measures for written

7. The coefficient of determination indicates the proportion of data explained by the model. 
production in a significant way, an observation which is the inverse of the outcomes for the English texts. In addition, the percentage of variance that the model predicts appears to be higher for the written productions in Dutch when compared to those in English. With the exception of the lexical diversity variable, the percentages are considerably higher, rising up to nearly $40 \%$ for text length.

Table 7. Regression models for the Dutch written productions. (ns=not significant)

\begin{tabular}{|c|c|c|}
\hline Measures & Regression coefficient and t-test statistic & $\begin{array}{l}\text { Coefficient of determination } \\
\text { and F-ratio }\end{array}$ \\
\hline Text length & $\begin{array}{l}\operatorname{CLIL}(\beta=.513, t=8.43, p<.001) \\
\text { Raven }-n s \\
\text { Length of TL instruction }-n s \\
\text { Current informal contact with TL }(\beta=.164, \\
t=2.79, p<.01)\end{array}$ & $\begin{array}{l}\left(R^{2}=.382, F(4,204)=31.544\right. \\
p<.001)\end{array}$ \\
\hline $\begin{array}{l}\text { Sentence } \\
\text { length }\end{array}$ & $\begin{array}{l}\text { CLIL }(\beta=.306, t=4.20, p<.001) \\
\text { Raven }(\beta=-.142, t=-2.08, p<.05) \\
\text { Length of TL instruction }-n s \\
\text { Current informal contact with TL }-n s\end{array}$ & $\begin{array}{l}\left(\mathrm{R}^{2}=.113, F(4,204)=6.510\right. \\
p<.001)\end{array}$ \\
\hline Word length & $\begin{array}{l}\operatorname{CLIL}(\beta=.317, t=4.52, p<.001) \\
\text { Raven }(\beta=.216, t=3.30, p<.01) \\
\text { Length of TL instruction }-n s \\
\text { Current informal contact with TL }-n s\end{array}$ & $\begin{array}{l}\left(R^{2}=.184, F(4,204)=11.522\right. \\
p<.001)\end{array}$ \\
\hline $\begin{array}{l}\text { Lexical } \\
\text { diversity }\end{array}$ & $\begin{array}{l}\operatorname{CLIL}(\beta=.228, t=3.28, p<.01) \\
\text { Raven }(\beta=.206, t=3.17, p<.01) \\
\text { Length of TL instruction }-n s \\
\text { Current informal contact with TL }(\beta=.138, \\
t=2.06, p<.05)\end{array}$ & $\begin{array}{l}\left(\mathrm{R}^{2}=.196, F(4,204)=12.440\right. \\
p<.001)\end{array}$ \\
\hline
\end{tabular}

\section{Discussion}

From the analyses presented above, a number of observations can be made. In response to our first research question (cf. 3.1), our results indicate that the written productions by the CLIL learners are overall more target-like than the ones of their non-CLIL peers, for both TLs. With respect to the relative importance of the examined input variables (research question 2), a first observation to be made is that CLIL is an important predictor of the learners' written productions. The CLIL variable correlates significantly with all four outcome measures in both TLs, and is often the strongest predictor in the regression analyses. These findings confirm our previous analyses (Bulon et al., 2017) and make a strong case for the 
CLIL approach as enhancing L2 writing, particularly with respect to fluency and lexical diversity. In this sense, our findings are in line with similar results found internationally (Dalton-Puffer, 2008; Gené-Gil et al., 2015; Jexenflicker \& DaltonPuffer, 2010; Lahuerta Martínez, 2015; Lo \& Murphy, 2010; Pérez-Vidal \& Roquet, 2015; Ruiz de Zarobe, 2010; Zydatiß, 2007).

Besides CLIL, we wanted to look at the relative impact of two different input measures, namely the amount of formal TL instruction (measured in number of years), and the degree to which the pupils are in informal contact with the TL outside school. Interestingly, the findings turned out to be very different for each of the TL conditions, with the results for the English texts showing the reverse picture of those obtained for the Dutch texts. Whereas the number of years of TL instruction that the learners received significantly predicts three of the four outcome measures for English, this variable was never significant for Dutch. Conversely, current informal contact with the TL is a significant predictor of text length and lexical diversity in the Dutch texts but does not appear to affect the pupils' writing skills in English. At first sight, these are rather puzzling results, since one would expect a somewhat similar picture for both TL learning conditions, also given the fact that we found significant correlations between these input variables and the outcome measures text length and lexical diversity for both Dutch (Table 4) and English (Table 5).

We wish to argue that these surprising results are likely due to the different status that English and Dutch enjoy as L2 languages in French-speaking Belgium, as already pointed out in Section 1. Rather unsurprisingly, English is considered to be the most important international language in Belgium and is omnipresent in everyday life (music, film, social media, etc.). Consequently, most of the pupils learning English have, at least to some extent, extracurricular contact with the language. On average, and as shown in Table 3a (Section 4.1), the English learners are at least 'sometimes' in contact with English outside school. Dutch, on the other hand, being the (non-international) language of the Flemish language community in Belgium, is on average less frequently used in informal contexts (e.g., on the internet), as can be derived from Table $3 \mathrm{~b}$. Therefore, the discriminatory power of the 'current informal contact' variable may be greater for Dutch - those pupils that are in contact with Dutch outside the classroom experience significant gains from this extra input - but neutralized for English since all English learners are to some extent in contact with English outside school. This would suggest that the potential impact of extracurricular input on learners' writing skills is subject to a ceiling effect: once a certain threshold of activity is reached, the variable ceases to be distinctive, at least as fluency (text length) and lexical diversity are concerned. Beyond that point, the amount of input received through formal 
instruction emerges as the predicting input variable, as reported here for the written productions of the English learners in our sample.

Finally, it should be noted that the significant correlations between the independent variables and the outcome measures are overall rather modest, indicating the importance of other variables that contribute to explaining variability in learners' written proficiency. Individual variables, such as language learning motivation or aptitude, are good candidates, as are classroom practices such as quantity and quality of language input, type of feedback, teaching style, etc. This finding is as such not surprising (Mitchell et al., 2017; Muñoz, 2014). Interestingly, however, the results from the regression analyses show us that the percentage of variance which is unaccounted for differs according to the TL condition. With the exception of lexical diversity, the present model appears to be better at predicting the outcome measures for the Dutch written productions than for the English ones, even though the values are rather low in Dutch too. These findings suggest that the variables unaccounted for play a larger role in explaining learners' variability for English. Also, the results from both the correlations and regression analyses suggest a larger impact of CLIL and the input measures on text length (fluency) and lexical diversity, whereas word and sentence length are less affected. These last two measures would thus appear to hinge less on the amount of input the pupils receive (be it formally or informally), but rather on other factors that were not included in the present study, such as perhaps the type of - and methods and tools used in - formal (writing) instruction. In addition, we acknowledge that more sophisticated and qualitative morphological and syntactic analysis of the texts is needed to gain a better understanding of the specific features of the learners' interlanguages. This is partly addressed in ongoing research that focuses on the L2 written productions of the same learners in the domain of the adjectival phrase (see Hendrikx, 2019, and Hendrikx et al., 2019, for more detailed analyses on intensifying phrases) and the verbal phrase (see Bulon, 2019, for more detailed analyses on verb-noun collocations).

\section{Conclusions}

The central aim of this study was to explore the impact of formal and informal input on learners' variability in writing, and to compare two TL conditions (Dutch and English) in CLIL and non-CLIL settings in French-speaking Belgium. Overall, we can conclude that the CLIL approach results in increased and 
more target-like L2 written proficiency, ${ }^{8}$ even when controlling for other types of input. Our findings thus contradict those reported on by Saladrigues and Llanes (2014), a contrast that can perhaps be partially explained by the difference in sample size, since their study was conducted on a very small sample (total $n=39$ ) of pupils from the same school. The CLIL advantage in our sample is most evident in terms of written fluency and lexical diversity. This finding runs parallel with international results regarding the CLIL effect on fluency and lexical diversity in oral productions (Dalton-Puffer, 2008). The results for sentence length and word length are less straightforwardly interpretable, but our analyses suggest that these variables are likely more dependent on other factors than the amount of input the learners were exposed to, factors which were outside the scope of the present study. Possible candidates of these additional factors are related to the type and quality of instructed input (such as for instance the teacher's TL proficiency), specific educational strategies, or types of teaching materials. However, variables such as these remain hard to quantify, and studies combining a quantitative and a qualitative approach would therefore be of great value. Möller's (2017) work on the acquisition of the passive, for instance, is one of the few studies that also analyses the teaching materials in CLIL and non-CLIL settings, thus combining a quantitative and a qualitative approach to input.

Regarding the influence of formal and informal input on written proficiency, we found that both types of input correlate with the pupils' writing skills, but that their relative impact on these skills differs starkly depending on the TL. The amount of formal language exposure predicts the outcomes of the English learners' written productions (written fluency, word length, and lexical diversity), and the frequency of informal exposure those of the Dutch learners (written fluency and lexical diversity). We argued that this observation could perhaps be accounted for by the difference in status that each of these languages holds among the pupils in our sample (and in the whole of French-speaking Belgium at that). A more favorable stance toward the 'cool' and international language English as opposed to Dutch, generally regarded as less attractive and more difficult, may explain why, on average, all learners of English report regular informal exposure to the TL, resulting in a loss of discriminatory power of this variable. By contrast, those learners of Dutch who are in contact with the TL outside school clearly benefit from the additional exposure they enjoy in informal contexts.

In any case, the fact that our results differ according to the TL has clear implications for (SLA) research looking at the effect of input on L2 learning. In fact,

8. The present study did not involve any qualitative analysis of the written productions, such as an investigation of the errors. We believe this may add to our analysis of the learners' writing skills and ongoing research is being carried out accordingly (among others, Bulon, 2019). 
different input variables do not only affect the various components of proficiency in different ways (e.g., Muñoz, 2008), but also the relative impact of these different input variables on the learners' proficiency apparently varies depending on the TL. Given the fact that most SLA and CLIL research is conducted with English as a TL, we believe this is an important finding and are prompting studies on TLs other than English.

\section{Funding}

This work was supported by a Concerted Research Action grant (ARC 14/19-061) from the Université catholique de Louvain (UCLouvain) and the Université de Namur (UNamur), awarded to Philippe Hiligsmann (spokesperson; UCLouvain), Benoît Galand (UCLouvain), Laurence Mettewie (UNamur), Fanny Meunier (UCLouvain), Arnaud Szmalec (UCLouvain) and Kristel Van Goethem (UCLouvain).

\section{Acknowledgements}

We would like to thank Audrey De Smet and Morgane Simonis for their assistance in the data collection. We also warmly thank the schools and participants that took part in the study.

\section{References}

Admiraal, W., Westhoff, G., \& de Bot, K. (2006). Evaluation of bilingual secondary education in the Netherlands: Students' language proficiency in English. Educational Research and Evaluation, 12(1), 75-93. https://doi.org/10.1080/13803610500392160

Bulon, A. (2019). The acquisition of phraseological units by French-Speaking learners of English and Dutch in CLIL and Non-CLIL settings: Exposure effects on range and accuracy. (Unpublished doctoral dissertation). UCLouvain, Louvain-la-Neuve, Belgium.

Bulon, A., Hendrikx, I., Meunier, F. \& Van Goethem, K. (2017). Using global complexity measures to assess second language proficiency: Comparing CLIL and non-CLIL learners of English and Dutch in French-speaking Belgium. Papers of the Linguistic Society of Belgium, 11(1), 1-25. <https://sites.uclouvain.be/bkl-cbl/wp-content/uploads /2017/o4/Bulon_et_al_2017.pdf>

Burstall, C. (1975). Factors affecting foreign-language learning: A consideration of some relevant research findings. Language Teaching and Linguistic Abstracts, 8, 105-125. https://doi.org/10.1017/So261444800002585

Carroll, J. B. (1969). Psychological and educational research into second language teaching to young children. In H.H. Stern (Ed.), Languages and the young school child (pp. 2-68). London: Oxford University Press. 
Celaya, M.L., \& Navés, T. (2009). Written production in English as a Foreign Language: agerelated differences and associated factors. In R. Manchón (Ed.), Learning, teaching and researching writing in foreign language learning contexts (pp. 130-155). Clevedon: Multilingual Matters. https://doi.org/10.21832/9781847691859-009

Celaya, M.L., Torras, M.R., \& Perez-Vidal, C. (2001). Short and mid-term effects of an earlier start: An analysis of EFL written production. Eurosla Yearbook, 1(1), 195-209. https://doi.org/10.1075/eurosla.1.15cel

Cenoz, J. (2002). Age differences in foreign language learning. ITL Review of Applied Linguistics, 135/136, 125-142. https://doi.org/10.1075/itl.135-136.06cen

Cenoz, J. (2003). Facteurs déterminant l'acquisition d'une L3: Age, développement cognitif et milieu. Acquisition et interaction en langue étrangère, $18,38-51$. $<$ http://journals .openedition.org/aile/1151>

Cenoz, J. (2015). Content-based instruction and content and language integrated learning: the same or different? Language, Culture and Curriculum, 28(1), 8-24. https://doi.org/10.1080/07908318.2014.1000922

Crossley, S.A., Salsbury, T., \& McNamara, D.S. (2014). Validating lexical measures using human scores of lexical proficiency. In S. Jarvis \& M. Daller (Eds.), Human ratings and automated measures (pp. 47-105). Amsterdam: John Benjamins.

Cumming, A. (1994). Writing expertise and second-language proficiency. In A. Cumming (Ed.), Bilingual performance in reading and writing (pp. 173-221). Ann Arbor, MI: Language Learning /John Benjamins.

Dalton-Puffer, C. (2008). Outcomes and processes in Content and Language Integrated Learning (CLIL): current research from Europe. In W. Delanoy \& V. Lauren (Eds.), Future perspectives for English language teaching (pp. 139-157). Heidelberg: Carl Winter.

Dalton-Puffer, C. (2011). Content-and-language integrated learning: From practice to principles? Annual Review of applied linguistics, 31, 182-204. https://doi.org/10.1017/So267190511000092

Dewaele, J.-M. (2005). Sociodemographic, psychological and politico-cultural correlates in Flemish students' attitudes towards French and English. Journal of Multilingual and Multicultural Development, 26(2), 118-137. https://doi.org/10.1080/01434630508668400

Ellis, R., \& Barkhuizen, G. P. (2005). Analysing learner language. Oxford: Oxford University Press.

García Lecumberri, M.L., \& Gallardo, M.P. (2003). English FL sounds in school learners of different ages. In M. P. García Mayo \& M. L. Garcia Lecumberri (Eds.), Age and the acquisition of English as a foreign language (pp. 115-135). Clevedon: Multilingual Matters. https://doi.org/10.21832/9781853596407-007

Gené-Gil, M., Juan-Garau, M., \& Salazar-Noguera, J. (2015). Development of EFL writing over three years in secondary education: CLIL and non-CLIL settings. The Language Learning Journal, 43(3), 286-303. https://doi.org/10.1080/09571736.2015.1053278

Graesser, A.C., McNamara, D. S., Louwerse, M.M., \& Cai, Z. (2004). Coh-Metrix: Analysis of text on cohesion and language. Behavior research methods, instruments \& computers, 36(2), 193-202. https://doi.org/10.3758/BFo3195564

Granger, S. (2015). Contrastive interlanguage analysis: A reappraisal. International Journal of Learner Corpus Research, 1(1), 7-24. https://doi.org/10.1075/ijlcr.1.1.01gra

Hendrikx, I. (2019). The acquisition of intensifying constructions in Dutch and English by French-speaking CLIL and non-CLIL students: Cross-linguistic influence and exposure effects. (Unpublished doctoral dissertation). UCLouvain, Louvain-la-Neuve, Belgium. 
Hendrikx, I., Van Goethem, K., \& Wulff, S. (2019). Intensifying constructions in Frenchspeaking L2 learners of English and Dutch: Cross-linguistic influence and exposure effects. International journal of Learner Corpus Research, 5(1), 63-103. https://doi.org/10.1075/ijlcr.18002.hen

Hiligsmann, Ph., Van Mensel, L., Galand, B., Mettewie, L., Meunier, F., Szmalec, A., Van Goethem, K., Bulon, A., De Smet, A., Hendrikx, I., \& Simonis, M. (2017). Assessing Content and Language Integrated Learning in the French-speaking Community of Belgium: Linguistic, cognitive and educational perspectives. Cahiers $d u$ GIRSEF, 109, 1-24. <https://cdn.uclouvain.be/groups/cms-editors-girsef/demey/Cahier_109_final.pdf > Isidro, X.S., \& Lasagabaster, D. (2018). The impact of CLIL on pluriliteracy development and content learning in a rural multilingual setting: A longitudinal study. Language Teaching Research, 1-19. https://doi.org/10.1177/1362168817754103

Jexenflicker, S., \& Dalton-Puffer, C. (2010). The CLIL differential: Comparing the writing of CLIL and non-CLIL students in higher colleges of technology. In C. Dalton-Puffer, T. Nikula \& U. Smit (Eds.), Language use and language learning in CLIL classrooms (pp. 169-190). Amsterdam: John Benjamins. https://doi.org/10.1075/aals.7.09jex

Johnson, J.S., \& Newport, E.L. (1989). Critical period effects in second language learning: The influence of maturational state on the acquisition of English as a second language. Cognitive Psychology, 21, 60-99. https://doi.org/10.1016/0010-0285(89)90003-0

Johnstone, R. (2007). Nationally-sponsored innovations at school in Scotland: issues of evidence, generalizability and sustainability. International Journal of Innovation in Language Learning and Teaching, 1(1), 111-128. https://doi.org/10.2167/illto46.0

Kinsella, C. (2009). An investigation into the proficiency of successful late learners of French. (Unpublished doctoral thesis). Trinity College, Dublin, Ireland.

Klieme, E. (2006). Zusammenfassung zentraler Ergebnisse der DESI Studie. Deutsches Institut für Internationale Pädagogische Forschung. <https://www.dipf.de/de/forschung/aktuelleprojekte/pdf/biqua/DESI_Ausgewaehlte_Ergebnisse.pdf>

Koizumi, R. (2012). Relationships between text length and lexical diversity measures: can we use short texts of less than 100 tokens? Vocabulary Learning and Instruction, 1(1), 60-69. https://doi.org/10.7820/vli.v01.1.koizumi

Lahuerta Martínez, A.C. (2015). Analysis of the written competence of secondary education students in bilingual and non-bilingual programmes. In Conference proceedings. ICT for language learning (pp. 499-503). Padova: Libreriauniversitaria.it Edizioni.

Lambelet, A., \& Berthele, R. (2015). Age and foreign language learning in school. Basingstoke: Palgrave MacMillan. https://doi.org/10.1057/9781137525901

Lasagabaster, D. (2008). Foreign language competence in content and language integrated courses. The Open Applied Linguistics Journal, 1, 31-42.

https://doi.org/10.2174/1874913500801010030

Lasagabaster, D., \& Doiz, A. (2003). Maturational constraints on foreign language written production. In M.P. García Mayo \& M.L. Garcia Lecumberri (Eds.), Age and the acquisition of English as a foreign language (pp. 136-160). Clevedon: Multilingual Matters. https://doi.org/10.21832/9781853596407-008

Llanes, À., \& Muñoz, C. (2009). A short stay abroad: Does it make a difference? System, 37(3), 353-365. https://doi.org/10.1016/j.system.2009.03.001

Lo, Y.-Y., \& Murphy, V.A. (2010). Vocabulary knowledge and growth in immersion and regular language-learning programmes in Hong Kong. Language and Education, 24, 215-238. https://doi.org/10.1080/09500780903576125 
Lochtman, K., Lutjeharms, M., \& Kermarrec, G. (2005). Langues étrangères à Bruxelles: recherche sur les attitudes d'étudiants Bruxellois des écoles d'ingénieur commercial ULB et VUB [Foreign languages in Brussels: research on the attitudes of students in Brussels]. In E. Witte, L. Van Mensel, M. Pierrard, L. Mettewie, A. Housen, \& R. De Groof (Eds.), Language, attitudes and education in multilingual cities (pp. 211-233). Brussels: Koninklijke Vlaamse Academie van België voor Wetenschappen en Kunst.

Long, M.H. (1983). Does second language instruction make a distinction? A review of research. TESOL quarterly, 17 (3), 359-382. https://doi.org/10.2307/3586253

Lorenzo, F., Casal, S., \& Moore, P. (2005). Orientaciones para la elaboración del currículo integrado de las lenguas en los centros bilingües. Seville: Consejería de Educación (Junta de Andalucía).

McCarthy, P.M., \& Jarvis, S. (2010). MTLD, vocd-D, and HD-D: A validation study of sophisticated approaches to lexical diversity assessment. Behavior Research Methods, 42(2), 381-392. https://doi.org/10.3758/BRM.42.2.381

Mettewie, L. (2015). Apprendre la langue de "l'Autre" en Belgique: la dimension affective comme frein à l'apprentissage [Learning the language of the 'Other' in Belgium]. Le Langage et l'Homme, 1(2), 23-42.

Miralpeix, I. (2006). Age and vocabulary acquisition in English as a foreign language. In C. Muñoz (Ed.), Age and the rate of foreign language learning (pp. 89-106). Clevedon: Multilingual Matters. https://doi.org/10.21832/9781853598937-006

Mitchell, R., Tracy-Ventura, N., \& McManus, K. (2017). Identity, social relationships and language learning during residence abroad. London/New York: Routledge.

Möller, V. (2017). Language acquisition in CLIL and non-CLIL settings: Learner corpus and experimental evidence on passive constructions. Amsterdam/Philadelphia: John Benjamins. https://doi.org/10.1075/scl.80

Moyer, A. (2009). Input as a critical means to an end: Quantity and quality of experience in L2 phonological attainment. In T. Piske \& M. Young-Scholten (Eds.), Input matters in SLA (pp. 159-174). Bristol: Multilingual Matters.

Muñoz, C. (2006). The effects of age on foreign language learning: The BAF Project. In C. Muñoz (Ed.), Age and the rate of foreign language learning (pp. 1-40). Clevedon: Multilingual Matters. https://doi.org/10.21832/9781853598937-003

Muñoz, C. (2008). Symmetries and asymmetries of age effects in naturalistic and instructed L2 learning. Applied Linguistics, 29, 578-596. https://doi.org/10.1093/applin/ammo56

Muñoz, C. (2011). Input and long-term effects of starting age in foreign language learning. IRAL-International Review of Applied Linguistics in Language Teaching, 49(2), 113-133. https://doi.org/10.1515/iral.2011.006

Muñoz, C. (2014). Contrasting effects of starting age and input on the oral performance of foreign language learners. Applied Linguistics, 35(4), 463-482. https://doi.org/10.1093/applin/amuo24

Myles, J. (2002). Second language writing and research: The writing process and error analysis in student texts. Tesl-Ej, 6(2), 1-20. <http://www.tesl-ej.org/wordpress/issues/volume6 /ej22/ej22a1/?wscr>

Pander Maat, H., Kraf, R., Dekker, N., Sloot, K. van der, Bosch, A. van den, Gompel, M. van, \& Klein, S. (2014). T-Scan: a new tool for analyzing Dutch text. Computational Linguistics in the Netherlands Journal, 4, 53-74. <https://repository.ubn.ru.nl/bitstream/handle/2066 /134833/134833.pdf?sequence $=1>$ 
Patkowski, M.S. (1980). The sensitive period for the acquisition of syntax in a second language. Language Learning, 30, 449-468. https://doi.org/10.1111/j.1467-1770.1980.tboo328.x

Pérez-Vidal, C., \& Juan-Garau, M. (2011). The effect of context and input conditions on oral and written development: A study abroad perspective. VIAL, Vigo international journal of applied linguistics, 4, 157-185. https://doi.org/10.1515/iral.2011.008

Pérez-Vidal, C., \& Roquet, H. (2015). The linguistic impact of a CLIL Science programme: An analysis measuring relative gains. System, 54, 80-90. https://doi.org/10.1016/j.system.2015.05.004

Raven, J.C., Court, J.H., \& Raven, J. (1998). Progressive coloured matrices. Oxford: Oxford Psychologists Press.

Roquet, H., \& Pérez-Vidal, C. (2017). Do productive skills improve in Content and Language Integrated Learning contexts? The case of writing. Applied Linguistics, 38(4), 489-511. https://doi.org/10.1093/applin/amvo50

Ruiz de Zarobe, Y. (2008). CLIL and foreign language learning: A longitudinal study in the Basque Country. International CLIL Research Journal, 1(1), 60-73. <http://www.icrj.eu/11 /article5.html>

Ruiz de Zarobe, Y. (2010). Written production and CLIL: An empirical study. In C. Dalton-Puffer, T. Nikula \& U. Smit (Eds.), Language use and language learning in CLIL classrooms (pp. 191-212). Amsterdam/Philadelphia: John Benjamins. https://doi.org/10.1075/aals.7.10rui

Saladrigues, G., \& Llanes, À. (2014). Examining the impact of amount of exposure on L2 development with CLIL and non-CLIL teenage students. Sintagma, 26, 133-147. <http:// www.raco.cat/index.php/Sintagma/article/view/293008/381457>

Simonis, M., Van der Linden, L., Galand, B., Hiligsmann, Ph., \& Szmalec, A. (2019). Executive control performance and foreign-language proficiency associated with immersion education in French-speaking Belgium. Bilingualism: Language and cognition, 1-16. https://doi.org/10.1017/S136672891900021X

Sundqvist, P. (2009). Extramural English matters: Out-of-school English and its impact on Swedish ninth graders' oral proficiency and vocabulary. (Unpublished doctoral dissertation). Karlstad University, Karlstad, Sweden.

Sundqvist, P., \& Wikström, P. (2015). Out-of-school digital gameplay and in-school L2 English vocabulary outcomes. System, 51, 65-76. https://doi.org/10.1016/j.system.2015.04.001

Torras, M.R., \& Celaya, M.L. (2001). Age-related differences in the development of written production. An empirical study of Efl school learners. International Journal of English Studies, 1(2), 103-126. <http://revistas.um.es/ijes/article/view/48211/46181>

Torras, M.R., Navés, T., Celaya, M.L., \& Pérez-Vidal, C. (2006). Age and IL development in writing. In C. Muñoz (Ed.), Age and the rate of foreign language learning (pp. 156-182). Clevedon: Multilingual Matters. https://doi.org/10.21832/9781853598937-0o9

Treffers-Daller, J. (2013). Measuring lexical diversity among L2 learners of French: an exploration of the validity of D, MTLD and HD-D as measures of language ability. In S. Jarvis \& M. Daller (Eds.), Vocabulary knowledge: Human ratings and automated measures (pp. 79-105). Amsterdam/Philadelphia: John Benjamins. https://doi.org/10.1075/sibil.47.05ch3

Van Mensel, L., Hiligsmann, Ph., Mettewie, L., \& Galand, B. (2019). CLIL, an elitist language learning approach? A background analysis of English and Dutch CLIL pupils in Frenchspeaking Belgium. Language, Culture, and Curriculum. https://doi.org/10.1080/07908318.2019.1571078 
Wesche, M. B. (2002). Early French immersion: How has the original Canadian model stood the test of time? In P. Thorsten, A. Rohde, H. Wode \& P. Burmeister (Eds.), An integrated view of language development: Papers in honor of Henning Wode (pp. 357-378). Trier: Wissenschaftlicher Verlag Trier.

White, L. (2003). On the nature of interlanguage representation: Universal Grammar in the second language. In C. J. Doughty \& M.H. Long (Eds.), The handbook of second language acquisition (pp. 19-42). Malden: Blackwell. https://doi.org/10.1002/9780470756492.ch2

Whittaker, A., \& Llinares, A. (2011). Written discourse development in CLIL at secondary school. Language Teaching Research, 15(3), 343-362. https://doi.org/10.1177/1362168811401154

Wode, H. (1994). Bilinguale Unterrichtserprobung in Schleswig-Holstein. Band II Analytische Auswertungen. Kiel: 1\&f Verlag.

Wolfe-Quintero, K., Inagaki, S., \& Kim, H.Y. (1998). Second language development in writing: Measures of fluency, accuracy, \& complexity. Hawaii: University of Hawaii Press.

Zydatiß, W. (2007). Deutsch-Englische Züge in Berlin (DEZIBEL). Eine Evaluation des bilingualen Sachfachunterrichts in Gymnasien: Kontext, Kompetenzen, Konsequenzen. Frankfurt am Main: Peter Lang.

\section{Appendix 1}

Frequency of informal contact with the TL outside school (Cronbach's alpha .78), on a scale from 1 to 5 (never - rarely - sometimes - often - very often), based on the following items:

\section{[Original in French]}

1. Sur internet, à quelle fréquence utilises-tu l'anglais/le néerlandais?

2. A quelle fréquence parles-tu l'anglais/le néerlandais en dehors de l'école?

3. A quelle fréquence entends-tu l'anglais/le néerlandais en dehors de l'école?

4. As-tu des contacts avec des anglophones/des néerlandophones en dehors de l'école ou de la maison?

\section{[English translation]}

1. How often do you use English/Dutch on the Internet?

2. How often do you speak English/Dutch outside school?

3. How often do you hear English/Dutch outside school?

4. Do you have any contact with English-speakers/Dutch-speakers outside school or home? 
Appendix 2

\begin{tabular}{lll}
\hline & Dutch CLIL/non-CLIL & English CLIL/non-CLIL \\
\hline & $U=1909,0$ & $U=2254,5$ \\
Words/text & $z=-9,27$, & $z=-5,14$, \\
& $p<.05^{\star}$ & $p<.05^{*}$ \\
& $r=-0,601$ & $r=-0,383$ \\
& $U=4257,5$ & $U=2539,5$ \\
Words/sentence & $z=-4,63$, & $z=-4,32$, \\
& $p<.05^{*}$ & $p<.05^{*}$ \\
& $r=-0,301$ & $r=-0,322$ \\
& $U=3889,0$ & $U=3250,5$ \\
Syllables/word & $z=-5,36$, & $z=-2,28$, \\
& $p<.05^{*}$ & $p<.05^{* *}$ \\
& $r=-0,352$ & $r=-0,170$ \\
& $U=3587,0$ & $U=2380,0$ \\
MTLD & $z=-5,95$, & $z=-4,78$, \\
& $p<.05^{*}$ & $p<.05^{*}$ \\
& $r=-0,391$ & $r=-0,356$ \\
\hline
\end{tabular}

\section{Résumé}

Cette étude s'inscrit dans le cadre d'un projet sur l'Enseignement d'une Matière par l'Intégration d'une Langue Étrangère (EMILE) en Belgique francophone. Elle vise à explorer l'impact de l'apport langagier (input) formel et informel sur les productions écrites des apprenants et à comparer deux conditions linguistiques (l'apprentissage du néerlandais et de l'anglais comme langues cibles) dans les contextes EMILE et non EMILE en Belgique francophone. Une analyse de régression montre que l'EMILE est un prédicteur significatif des résultats pour les deux langues cibles, mais que l'impact relatif de l'input formel et informel differe selon la langue cible. En bref, le degré d'exposition formelle à la langue cible prédit les résultats des productions écrites des apprenants de l'anglais, et la fréquence de l'exposition informelle ceux des apprenants du néerlandais. Nous soutenons que cette observation est probablement liée à la différence de statut de chacune de ces langues parmi les élèves de notre échantillon. Les résultats soulignent donc l'importance du statut de la L2 dans la recherche sur l'EMILE, puisque différentes langues cibles peuvent donner des résultats différents. 


\section{Address for correspondence}

Luk Van Mensel

Namur Institute of Language, Text and Transmediality

Université de Namur

61, rue de Bruxelles

B-500o Namur

Belgium

luk.vanmensel@unamur.be

iD https://orcid.org/oooo-0003-0438-586o

\section{Co-author information}

Amélie Bulon

Institut Langage et Communication UCLouvain

amelie.bulon@uclouvain.be

Isa Hendrikx

Institut Langage et Communication

UCLouvain

isa.hendrikx@uclouvain.be
Fanny Meunier

Institut Langage et Communication UCLouvain

fanny.meunier@uclouvain.be

Kristel Van Goethem

F.R.S.-FNRS \& UCLouvain

kristel.vangoethem@uclouvain.be

\section{Publication history}

Date received: 31 August 2018

Date accepted: 1 December 2019

Published online: 1 May 2020 